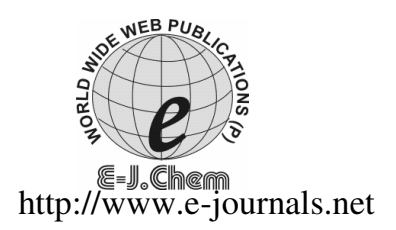

ISSN: 0973-4945; CODEN ECJHAO

E-Journal of Chemistry

2011, 8(4), 1720-1727

\title{
Synthesis, Isolation and Characterization of Process-Related Impurities in Salbutamol Sulphate
}

\author{
YOGESH KUMAR SHARMA*, DAU DAYAL AGARWAL, SUDESH BHURE, \\ RAJENDRA NATH MUKHARJEE, PRAMOD KUMAR SAHU \\ and SANTOSH BHARDWAJ \\ *Department of Industrial Chemistry, Jiwaji University \\ Gwalior-475011, Madhya Pradesh, India \\ Pharmasolve Specialities (I) Pvt. Ltd. Mumbai, India \\ sharmayogesh9182@rediffmail.com
}

Received 14 March 2011; Accepted 20 April 2011

\begin{abstract}
Three known and one unknown impurities in salbutamol sulphate bulk drug at level $0.1 \%$ (ranging from $0.05-0.1 \%$ ) were detected by gradient reverse phase high performance liquid chromatography. These impurities were preliminarily identified by the mass number of the impurities. Different experiments were conducted and finally synthesized and characterized the known and unknown imputities.
\end{abstract}

Keywords: Salbutamol sulphate, Impurities, Synthesis, Isolation and Characterization

\section{Introduction}

Salbutamol sulphate is a relatively selective 2-adrenergic agonist and is used as a bronchodilator. The chemical name of salbutamol sulfate is 1-(4-hydroxy-3hydroxymeth ylphenyl)-2-(tert-butylamino) ethanol sulfate (2:1) (salt) salbutamol sulfate is indicated for the prevention and relief of bronchospasm with reversible obstructive airway disease (asthma) and for the prevention of exercise induced bronchospasm. It is also indicated for the management of acute attacks of bronchospasm. Salbutamol sulfate acts by stimulating the adenyl cyclase enzyme, which catalyzes the formation of cyclic-3,5-adenosine monophosphate (cyclic AMP) from adenosine triphosphate (ATP) ${ }^{1-2}$.

There are several process impurities/related substances associated with the manufacture of salbutamol sulfate. Different process related impurities have been observed with various synthetic routes and/or manufacturing processes. Ten of the known salbutamol related substances have been mentioned in Europian Pharmacopoeia $6.0^{3}$. All these impurities are never present together while we are preparing bulk drug or preparing formulation. 
The Europian Pharmacopoeia ${ }^{3}$ specifies that individual impurity is not more than $0.3 \%$ and total impurity is not more than $1.0 \%$. The British Pharmacopoeia ${ }^{4}$ specifies that the related impurities which is determined by TLC, to be maximum of $0.5 \%$. The united states pharmacopoeia ${ }^{5}$ requires that the sum of the impurities in salbutamol sulphate should not be greater than $2.0 \%$.

During the process development of salbutamol sulphate three known and one unknown impurities were identified in the analysis of different batches whose percent area ranged from $0.05-0.1 \%$ by HPLC ${ }^{3-5}$. A comprehensive study has been carried out to isolate or to prepare and characterize these impurities. To the best of our knowledge, synthesis rout of impurities is novel and not reported in literature. Due to the importance of regulatory authorities $^{6}$ and all the impurities should be at the level of $>0.1 \%$ must identify and characterized.

A literature search revealed that only analytical procedure ${ }^{7-9}$ is available but nobody has reported synthesis, isolation and characterization of impurities in the purified form starting from salbutamol sulphate. The present communication involves the isolation or preparation of impurities and characterized by chromatographic and spectroscopic techniques ${ }^{10}$.

\section{Experimental}

The investigated samples of bulk salbutamol sulphate were received from Pharmasolve Specialities (I) Pvt. Ltd. Mumbai.

\section{High performance liquid chromatography (HPLC)}

An in-house LC method was developed for the reaction monitoring of salbutamol impurities. A Shimadzu model LC2010CHT equipped with a UV detector was used. The chromatographic condition optimized were ODS, $50 \times 4.6 \mathrm{~mm}, 3 \mu$ column with a mobile phase -A consisting 950:50(v/v) of $0.02 \mathrm{M} \mathrm{KH}_{2} \mathrm{PO}_{4}$ buffer and acetonitrile and mobile phase -B consisting 600:400(v/v) of $0.02 \mathrm{M} \mathrm{KH}_{2} \mathrm{PO}_{4}$ buffer and acetonitrile with a timed gradient programme of T/\%B:0/0,3/0,8/50,15/50,16/0,20/0. Detection was carried out at $220 \mathrm{~nm}$ and the flow rate $1.0 \mathrm{~mL} / \mathrm{min}$. Data was recorded by using LC solutions software.

\section{High performance liquid chromatography (preparative)}

An in-house LC method was developed for the isolation of salbutamol sulphate impurities. A waters LC controller equipped with a UV detector was used. The prep-HPLC method uses a C18 column (YMC Pack Pro.C-18,250 mm $20 \mathrm{~mm}$ i.d.,10 um particle size) with a mobile phase A consisting of $0.02 \mathrm{M}$ ammonium acetate and mobile phase $\mathrm{B}$ consisting acetonitrile timed gradient programme of T/\%B: 0/0, 5/5, 10/10, 15/20, 20/50, 25/50, 30/80, 35/80, 36/0, 40,0. Detection was carried out at $225 \mathrm{~nm}$ and the flow rate was $15.0 \mathrm{~mL} / \mathrm{min}$. Data was recorded by using empower software.

\section{Mass spectrometry}

Electrospray ionization mass spectroscopy was performed using an ion trap mass spectrometer (Model 6310 agilent). The positive and negative electrospray MS data was obtained by switching the capillary voltage between $n+5000$ and $-4500 \mathrm{~V}$ respectively.

\section{NMR spectroscopy}

The NMR experiments were performed on Bruker avance II $400 \mathrm{MHz}$.The ${ }^{1} \mathrm{H}$ chemical shift values were reported on the $\delta$ scale in ppm, relative to TMS $(\delta=0.00)$ and the ${ }^{13} \mathrm{C}$ chemical 
shift values were reported relative to $\mathrm{CDCl}_{3}(\delta=77.00 \mathrm{ppm})$ and DMSO, d6 $(\delta=39.50 \mathrm{ppm})$ as internal standards. ${ }^{1} \mathrm{H}$ and ${ }^{13} \mathrm{C}$ experiment was run using a mixing time of $1000 \mathrm{~ns}$.

FT-IR spectroscopy

The IR spectra were recorded in the solid state as $\mathrm{KBr}$ dispersion medium using Perkin Elmer spectrum 100 FT-IR spectrophotometer.

\section{Synthesis of impurities}

\section{Synthesis of impurity 1, 2 and 3}

Salbutamol base ( $2 \mathrm{~g}$ ) was charged into one neck round bottom flask with magnetic stirrer. Methanol $(50 \mathrm{~mL})$ was added and stirring was started. $\mathrm{NaOH}(2 \mathrm{~g})$ was added very slowly and again methanol $(50 \mathrm{~mL})$ was introduced to dissolve the base completely. The contents were stirred slowly with heating. The samples were checked using HPLC. The HPLC analysis showed 3 peaks separately which confirm the presence of three different impurities. The peaks were purified using preparative HPLC and marked as fraction-1, 2 and 3 (Scheme 1).

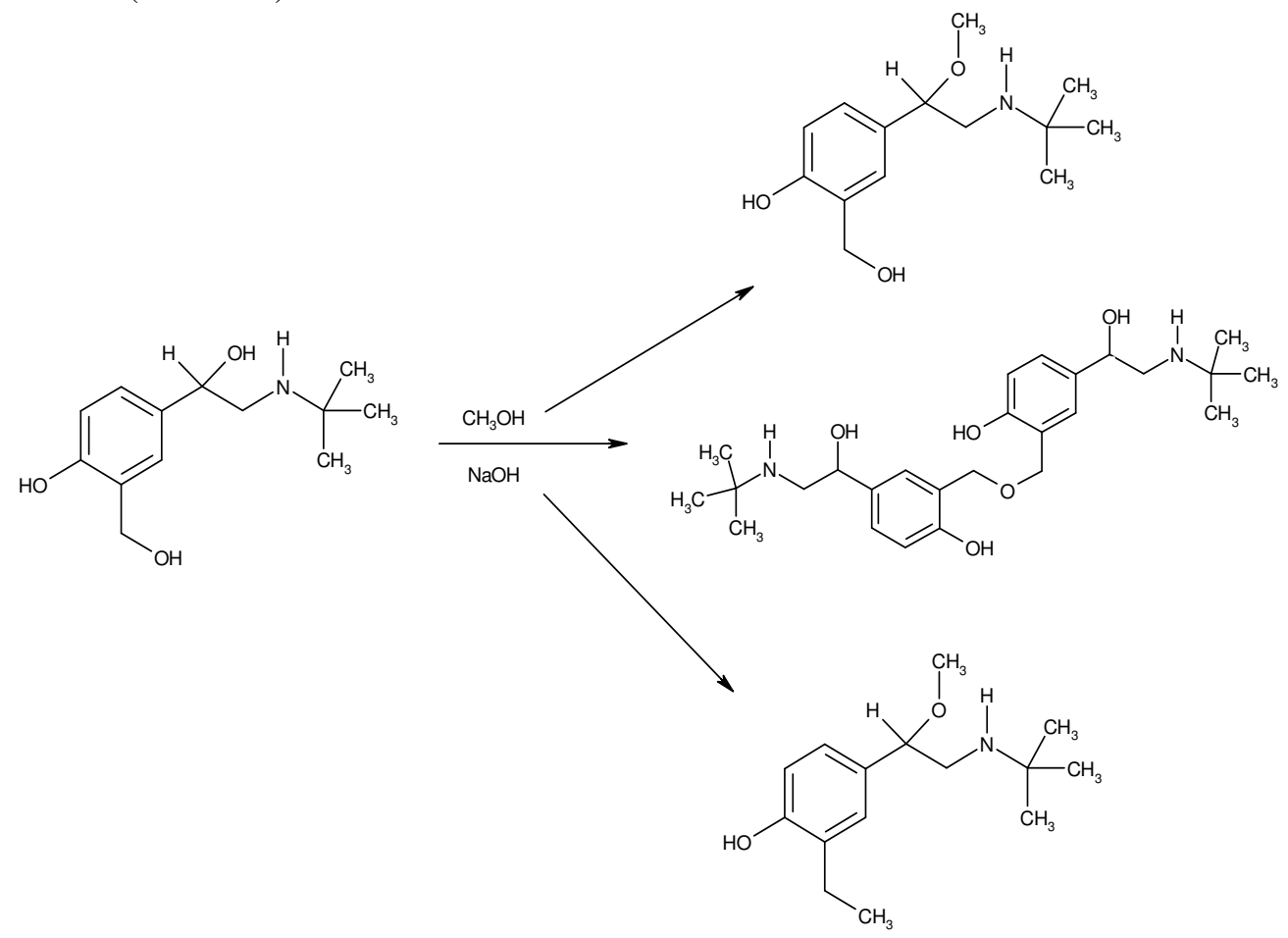

Scheme 1. Synthesis of impurity 1, 2 and 3

\section{Synthesis of impurity 4}

Salbutamol base $2 \mathrm{~g}$ was charged with $50 \mathrm{~mL}$ acetone into one neck round bottom flask with magnatic stirrer $\mathrm{K}_{2} \mathrm{CO}_{3}(1.2 \mathrm{~g})$ was added and heating started with stirring. To this benzylchloride $1.1 \mathrm{~g}$ was added and contents refluxed for $12 \mathrm{~h}$. After $12 \mathrm{~h}$ the reaction mass was checked using HPLC. The HPLC analysis showed 1 peak separately which confirm the presence of one different impurity. This peak was purified using preparative HPLC and marked as fraction-4 (Scheme 2). 


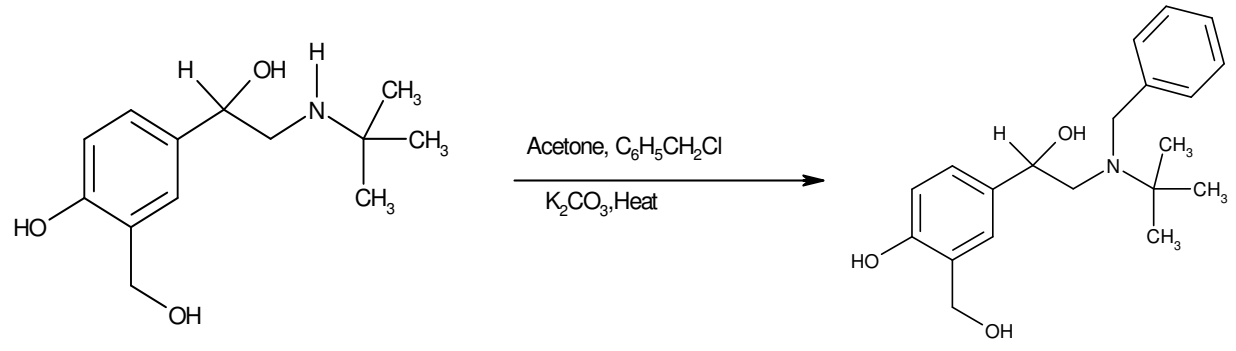

Scheme 2. Synthesis of impurity 4

\section{Results and Discussion}

Structure elucidation of impurity 1(Impurity-1)

Sample was analyzed by HPLC and its purity was found to be $93.14 \%$, molecular weight of salbutamol sulphate impurity-1 is 253.34 which is 14 mass unit higher than that of salbutamol sulphate. The ESI mass spectrum of sample gave a protonated molecular ion at $\mathrm{m} / \mathrm{z}, 254.1$ and deprotonated molecular ion at $\mathrm{m} / \mathrm{z} 252.6$ which is the same as salbutamol sulphate impurity-1 ${ }^{27-30}$, IR spectrum displayed characteristic absorptions at $3398.89 \& 2982.02,2934.06 \mathrm{~cm}^{-1}$ corresponding to $>\mathrm{NH}$ and aromatic $>\mathrm{CH}$ stretching . The peaks at $1509.95 \& 1452.92 \mathrm{~cm}^{-1}$ in IR spectrum is indicative of $>\mathrm{C}=\mathrm{C}<$ ring stretching, the chemical shift of the ${ }^{1} \mathrm{H}$ signals showed an additional signal at $3.15 \mathrm{ppm}$ as singlet, which could be attributed to a methoxy group present in impurity $-1,{ }^{13} \mathrm{C}$ signals showed an additional signal at $49.84 \mathrm{ppm}$, which could be attributed to a methoxy group present in impurity-1. HPLC purity $93.14 \%$, mass $+\mathrm{ve} \mathrm{m} / \mathrm{z}$ 254.1 and -ve $\mathrm{m} / \mathrm{z} 252.6$ (Table 1), IR (KBr): 3398.89, 2982.02, 2934.06, 1509.66, 1452.92 (Table 1); ${ }^{1} \mathrm{H}$ NMR: $1.09(\mathrm{~s}, 9 \mathrm{H}), \quad 1.21(\mathrm{~d}, 1 \mathrm{H}), \quad 2.58-2.80 \quad(\mathrm{dd}, 2 \mathrm{H}), \quad 4.17-$ $4.20(\mathrm{~d}, 1 \mathrm{H}), 6.98-7.00(\mathrm{dd}, 1 \mathrm{H}), 6.76-6.78(\mathrm{~d}, 1 \mathrm{H}), 7.21-7.21(\mathrm{~d}, 1 \mathrm{H}), 4.59(\mathrm{~s}, 2 \mathrm{H}), 3.15(\mathrm{~s}, 3 \mathrm{H})$ (Scheme 3, Table 2); ${ }^{13} \mathrm{C}$ NMR: 27.60, 58.85, 48.54, 82.05, 129.38, 125.21, 114.04, 153.71, 127.23, 125.24, 55.26, 49.84 (Scheme 4, Table 3).

Table 1. IR and mass spectral data of impurities

\begin{tabular}{|c|c|c|c|}
\hline S.No. & Compound & IR $\mathrm{cm}^{-1}$ & MS \\
\hline 1 & Impurity-1 & $\begin{array}{l}3398.89(>\mathrm{N}-\mathrm{H}) \\
2982.02,2934.06(\text { Aromatic }>\mathrm{C}-\mathrm{H}) \\
1509.66,1452.92(>\mathrm{C}=\mathrm{C}<)\end{array}$ & $\begin{array}{l}\text { +ve } m / z 254.1 \\
\text {-ve } m / z 252.6\end{array}$ \\
\hline 2 & Impurity-2 & $\begin{array}{l}3420.37(>\mathrm{N}-\mathrm{H}) \\
2973.72,2941.87(\text { Aromatic }>\mathrm{C}-\mathrm{H}) \\
1514.91,1478.62(>\mathrm{C}=\mathrm{C}<)\end{array}$ & $\begin{array}{l}\text { +ve } m / z 461.3 \\
\text {-ve } m / z 459.5\end{array}$ \\
\hline 3 & Impurity-3 & $\begin{array}{l}3420.37(>\mathrm{N}-\mathrm{H}) \\
2973.72,2941.87(\text { Aromatic }>\mathrm{C}-\mathrm{H}) \\
1514.91,1478.62(>\mathrm{C}=\mathrm{C}<)\end{array}$ & $\begin{array}{l}\text { +ve } m / z 252.1 \\
\text {-ve } m / z 251.6\end{array}$ \\
\hline 4 & Impurity-4 & $\begin{array}{l}3428.93(>\mathrm{N}-\mathrm{H}) \\
2981.68,2862.63(\text { Aromatic }>\mathrm{C}-\mathrm{H}) \\
1500.88,1454.21(>\mathrm{C}=\mathrm{C}<)\end{array}$ & +ve $m / z 330.2$ \\
\hline
\end{tabular}


<smiles>COC(CN(C)C(C)(C)C)c1ccc(O)c(CO)c1</smiles><smiles>CCc1cc(C(CN(C)C(C)(C)C)OC)ccc1O</smiles>
Impurity 3<smiles>CN(CC(O)c1ccc(O)c(COCc2cc(C(O)CN(C)C(C)(C)C)ccc2O)c1)C(C)(C)C</smiles>

Impurity 2<smiles>CC(C)(C)N(Cc1ccccc1)CC(O)c1ccc(O)c(CO)c1</smiles>

Impurity 4

Scheme 3. ${ }^{1} \mathrm{H}$ NMR assignment of impurities $1,2,3$ \& 4

\section{Structure elucidation of impurity 2(Impurity-2)}

Sample was analyzed by HPLC and its purity was found to be $87.93 \%$, molecular weight of salbutamol sulphate impurity-2 is 460.62 which is 221 mass unit higher than that of salbutamol sulphate. The ESI mass spectrum of sample gave a protonated molecular ion at $\mathrm{m} / \mathrm{z} 461.3$ and deprotonated molecular ion at $\mathrm{m} / \mathrm{z} 459.5$ which is the same as salbutamol sulphate impurity-2, IR spectrum displayed characteristic absorptions at 3420.37 \& $2973.72,2941.87 \mathrm{~cm}^{-1}$ corresponding to $>\mathrm{NH}$ and aromatic $>\mathrm{CH}$ stretching. The peaks at $1514.91 \& 1478.62 \mathrm{~cm}^{-1}$ in IR spectrum is indicative of $>\mathrm{C}=\mathrm{C}<$ ring Stretching, ${ }^{1} \mathrm{H}$ signals showed no additional signal observed but the multiplicity of signals were double this confirm the structure of salbutamol sulphate impurity-2, ${ }^{13} \mathrm{C}$ signals show no additional signal but the multiplicity of signals were double. HPLC purity $87.93 \%$, mass +ve $\mathrm{m} / \mathrm{z} 461.3$ and -ve $\mathrm{m} / \mathrm{z}$ 459.5(Table 1), IR (KBr): 3420.37, 2973.72, 2941.87, 1514.91,1478.62 (Table 1); ${ }^{1} \mathrm{H}$ NMR: 1.18-119(d,18H), 1.34(s, 2H), 2.71-2.84(dd, 4H), 3.15-3.40(m, 2H), 6.90-7.09 (m, 2H), 6.67-6.83(m, 2H), 7.28-7.56(m, 2H), 4.59-4.68(m, 4H), 10.05(s, 2H) (Scheme 3, Table 2); ${ }^{13} \mathrm{C}$ NMR: 26.04, 58.00, 48.98, 73.30, 132.81, 124.86, 113.92, 153.2, 124.75, 127.99 (Scheme 4, Table 3)<smiles>COC(CNC(C)(C)C)c1ccc(O)c(CO)c1</smiles>

Impurity 1<smiles>CC(C)(C)NCC(O)c1ccc(O)c(COCc2cc(C(O)CNC(C)(C)C)ccc2O)c1</smiles>

Impurity 2 


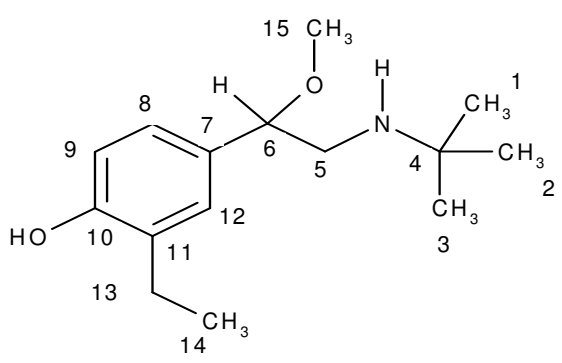

Impurity 3

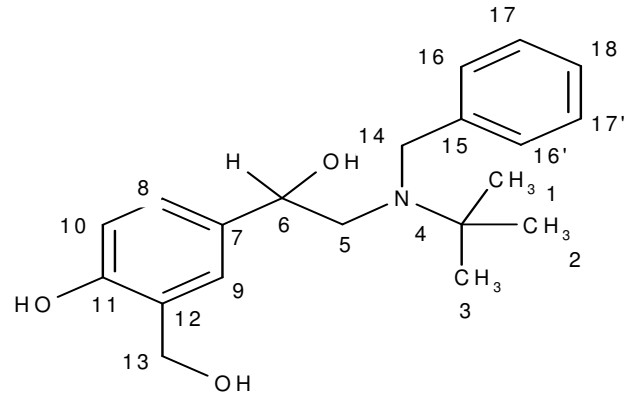

Impurity 4

Scheme 4. ${ }^{13} \mathrm{C}$ NMR assignment of impurities $1,2,3 \& 4$

\section{Structure elucidation of impurity 3(Unknown impurity)}

Sample was analyzed by HPLC and its purity was found to be $96.72 \%$, molecular weight of salbutamol sulphate impurity-3 is 251.37 which is 12 mass unit higher than that of salbutamol sulphate. The ESI mass spectrum of sample gave a protonated molecular ion at $m / z 252.1$ and deprotonated molecular ion at $\mathrm{m} / z$ 250.6.which confirm that molecular weight is 251 . Of salbutamol sulphate impurity-3, IR spectrum displayed characteristic absorptions at 3433.68 \& $2972.11,2929.11 \mathrm{~cm}^{-1}$ corresponding to $>\mathrm{NH}$ and aromatic $>\mathrm{CH}$ stretching. The peaks at $1514.60 \& 1478.83 \mathrm{~cm}^{-1}$ in IR spectrum is indicative of $>\mathrm{C}=\mathrm{C}<$ ring stretching, ${ }^{1} \mathrm{H}$ signals showed additional signals at $2.56 \& 1.10-1.13 \mathrm{ppm}$ as singlet \& triplate, which could be attributed to a methoxy \& methyl group present in impurity-3, ${ }^{13} \mathrm{C}$ signals showed additional signal at $15.05 \& 78.52 \mathrm{ppm}$, which could be attributed to a methoxy \& methyl group present in impurity-3. HPLC purity $97.72 \%$, mass +ve $\mathrm{m} / \mathrm{z} 252.1$ and -ve $\mathrm{m} / \mathrm{z} 250.6$ (Table 1), IR (KBr): 3420.37, 2973.72, 2941.87, 1514.91, 1478.62(Table 1); ${ }^{1} \mathrm{H}$ NMR: 1.07(s, 9H), $1.19(\mathrm{~s}, 1 \mathrm{H}), 2.73-2.78(\mathrm{dd}, 2 \mathrm{H}), 4.20-4.23(\mathrm{dd}, 1 \mathrm{H}), 6.89-6.92(\mathrm{dd}, 1 \mathrm{H}), 6.73-6.75(\mathrm{~d}, 1 \mathrm{H}), 6.96-$ 6.97(d, 1H), 3.24-3.36(m, 2H), 2.56(s, 3H), 9.06(s, 1H), 1.10-1.13(t, 3H) (Scheme 3, Table 2); ${ }^{13} \mathrm{C}$ NMR: $28.45,63.04,49.28,80.92,130.81,124.58,114.18,154.71,123.60,128.57$, 15.05, 78.52 (Scheme 4, Table 3).

Table 2. ${ }^{1} \mathrm{H}$ NMR spectral data of impurities $1,2,3$ \& 4

\begin{tabular}{|c|c|c|c|c|c|c|c|c|}
\hline \multirow[b]{2}{*}{ S.No. } & \multicolumn{2}{|c|}{ Impurity 1} & \multicolumn{2}{|c|}{ Impurity 2} & \multicolumn{2}{|c|}{ Impurity 3} & \multicolumn{2}{|c|}{ Impurity 4} \\
\hline & $\delta, \mathrm{ppm}$ & $\mathrm{H}$ & $\delta, \mathrm{ppm}$ & $\mathrm{H}$ & $\delta, \mathrm{ppm}$ & $\mathrm{H}$ & $\delta, \mathrm{ppm}$ & $\mathrm{H}$ \\
\hline $1,2,3$ & 1.09 & $9 \mathrm{H}$ & $1.18-119$ & $18 \mathrm{H}$ & 1.07 & $9 \mathrm{H}$ & 1.21 & $9 \mathrm{H}$ \\
\hline 4 & 1.21 & $1 \mathrm{H}$ & 1.34 & $2 \mathrm{H}$ & 1.19 & $1 \mathrm{H}$ & 4.66 & $2 \mathrm{H}$ \\
\hline 5 & $2.58-2.80$ & $2 \mathrm{H}$ & $2.71-284$ & $4 \mathrm{H}$ & $2.73-2.78$ & $2 \mathrm{H}$ & $2.74-2.83$ & $2 \mathrm{H}$ \\
\hline 6 & $4.17-4.20$ & $1 \mathrm{H}$ & $3.15-3.40$ & $2 \mathrm{H}$ & $4.20-4.23$ & $1 \mathrm{H}$ & $4.77-4.78$ & $1 \mathrm{H}$ \\
\hline 7 & $6.98-7.00$ & $1 \mathrm{H}$ & $6.90-7.09$ & $2 \mathrm{H}$ & $6.89-6.92$ & $1 \mathrm{H}$ & $7.22-7.24$ & $1 \mathrm{H}$ \\
\hline 8 & $6.76-6.78$ & $1 \mathrm{H}$ & $6.67-6.83$ & $2 \mathrm{H}$ & $6.73-6.75$ & $1 \mathrm{H}$ & $6.88-6.90$ & $1 \mathrm{H}$ \\
\hline 9 & $7.21-7.21$ & $1 \mathrm{H}$ & $7.28-7.56$ & $2 \mathrm{H}$ & $6.96-6.97$ & $1 \mathrm{H}$ & $7.29-7.30$ & $1 \mathrm{H}$ \\
\hline 10 & 4.59 & $2 \mathrm{H}$ & $4.59-4.68$ & $4 \mathrm{H}$ & $3.24-3.36$ & $2 \mathrm{H}$ & 5.09 & $2 \mathrm{H}$ \\
\hline 11 & 3.15 & $3 \mathrm{H}$ & & & 2.56 & $3 \mathrm{H}$ & & \\
\hline 12 & & & 10.05 & $2 \mathrm{H}$ & 9.06 & $1 \mathrm{H}$ & & \\
\hline 13 & & & & & $1.10-1.13$ & $3 \mathrm{H}$ & & \\
\hline $14,14^{\prime}$ & & & & & & & $7.31-7.36$ & $2 \mathrm{H}$ \\
\hline $15,15^{\prime}$ & & & & & & & $7.38-7.43$ & $2 \mathrm{H}$ \\
\hline 16 & & & & & & & 7.47 & $1 \mathrm{H}$ \\
\hline
\end{tabular}


Table 3. ${ }^{13} \mathrm{C}$ NMR spectral data of impurities $1,2,3 \& 4$

\begin{tabular}{clccc}
\hline Carbon assignment & Impurity 1 & $\begin{array}{c}\text { Impurity } 2 \\
\text {, in ppm }\end{array}$ & Impurity 3 & Impurity 4 \\
\hline $1,2,3$ & 27.60 & 26.04 & 28.45 & 27.04 \\
4 & 58.85 & 58.00 & 63.04 & 52.60 \\
5 & 48.54 & 48.98 & 49.28 & 69.45 \\
6 & 82.05 & 73.30 & 80.92 & 70.26 \\
7 & 129.38 & 132.81 & 130.81 & 135.03 \\
8 & 125.21 & 124.86 & 124.58 & 125.03 \\
9 & 114.04 & 113.92 & 114.18 & 125.19 \\
10 & 153.71 & 153.2 & 154.71 & 110.99 \\
11 & 127.23 & 124.75 & 123.60 & 154.49 \\
12 & 125.24 & 127.99 & 128.57 & 130.40 \\
13 & 55.26 & 58.00 & 63.04 & 58.78 \\
14 & 49.84 & & 15.05 & 49.64 \\
15 & & & 78.52 & 137.09 \\
16,16 & & & & 128.31 \\
17,17 & & & & 127.02 \\
18 & & & & 127.61 \\
\hline
\end{tabular}

Structure elucidation of impurity 4(Impurity-4)

Sample was analyzed by HPLC and its purity was found to be $99.45 \%$, molecular weight of salbutamol sulphate impurity-4 is 329.44 which is 90 mass unit higher than that of salbutamol sulphate. The ESI mass spectrum of sample gave a protonated molecular ion at $\mathrm{m} / \mathrm{z} 330.2$ which is the same as salbutamol sulphate impurity-4, IR spectrum displayed characteristic absorptions at $3428.93 \& 2981.68,2862.63 \mathrm{~cm}^{-1}$ corresponding to $>\mathrm{NH}$ and aromatic $>\mathrm{CH}$ stretching. The peaks at $1500.88 \& 1454.21 \mathrm{~cm}^{-1}$ in IR spectrum is indicative of $>\mathrm{C}=\mathrm{C}<$ ring Stretching, ${ }^{1} \mathrm{H}$ signals showed additional signals at 7.31-7.36,7.38-7.43 $\& 7.47 \mathrm{ppm}$ as 2 multiplet \& singlet which could be attributed to a aromatic ring as reported in impurity E, ${ }^{13} \mathrm{C}$ signals showed additional signal at 49.64,137.09,128.31,127.02\& $127.61 \mathrm{ppm}$, which could be attributed to a additional aromatic ring present in impurity-4. HPLC purity 99.45\%, mass +ve $\mathrm{m} / \mathrm{z} 330.2$ (Table 1), IR (KBr): 3428.93, 2981.68, 2862.63, 1500.88, 1454.21 (Table 1); ${ }^{1} \mathrm{H}$ NMR: 1.21(s, 9H), 4.66(s, 2H), 2.74-2.83(dd, 2H), 4.77-4.78(d, 1H), 7.22-7.24(d, 1H), 6.88-6.90(d, 1H), 7.29-7.30(d, 1H), 5.09(s, 2H), 7.31-7.36(m, 2H), 7.387.43(m, 2H), 7.47(s, 1H) (Scheme 3, Table 2) ; ${ }^{13} \mathrm{C}$ NMR: 27.04, 52.60, 69.45, 70.26, 135.03 , 125.03, 125.19, 110.99, 154.49, 130.40, 58.78, 49.64, 137.09, 128.31, 127.02, 127.61 (Scheme 4, Table 3).

\section{Conclusion}

This research paper describes the synthesis, isolation and structure elucidation of process related impurities in salbutamol sulphate. The impurities were separated by reverse phase chromatographic technique, further isolated by semipreparative liquid chromatography. The isolated impurities were characterized using spectroscopic techniques. This isolated impurities were used for mass balance of salbutamol sulphate technical material. The synthesis of impurities was also discussed in brief. 


\section{Acknowledgment}

We are grateful to Mr.Sanjay Singh Rathore, R.ganga Prasad, Praveen Sharma and Mr. Avtar Singh, Shophisticated Analytical Instrumentation Facility, Chandigarh and Punjab University, Chandigarh for spectral analytical data.

\section{References}

1. Satyajit V E, Cindy B F and Asif M, J Pharm Biomed Anal., 2006, 40(4), 864-874.

2. Bernal J L, del Nozal M J, Rivera J M, Serna M L and Toribio L, Chromatographia, 1996, 42(1-2), 89-94.

3. European Pharmacopeia, European Directorate for the Quality of Medicines \& Health Care, 2007, 2.

4. British Pharmacopoeia, The British Pharmacopoeia Commission. The Stationary Office, London, UK. 2001, Vol.1.

5. United State Pharmacopeia, National Formulary, Asian USP 32 NF 27, 2009.

6. International Conference on Harmonization, Draft Revised. Federal Register Q3B(R), 2000, 65(139), 44791.

7. Bernal J L, del Nozal M, Velasco $\mathrm{H}$ and Torbio L, J Liq Chrom Rel Technol.,1996,19,1579-1589.

8. Manus D, Rogan M, Altria K D and Goodall D M, Wiley Int Sci England, 2005, 15(1), 808-817.

9. Beaulieu N, Cyr T D and Lovering E G, J Pharm Biomed Anal., 1990, 8, 583-589.

10. Silverstein R M and Webster F X, Spectrometric Identification of Organic compounds. Sixth Edition, Wiley India, 2002 


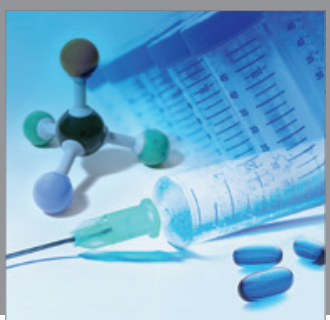

International Journal of

Medicinal Chemistry

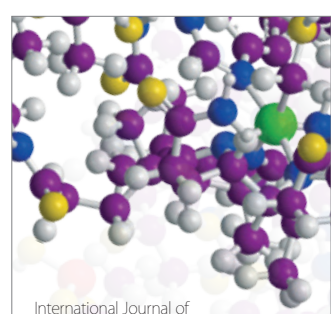

Carbohydrate Chemistry

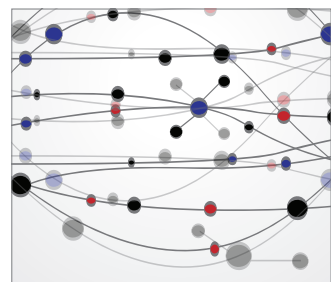

The Scientific World Journal
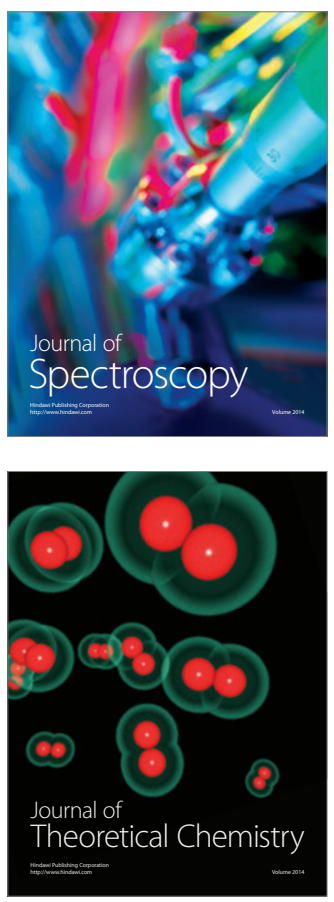
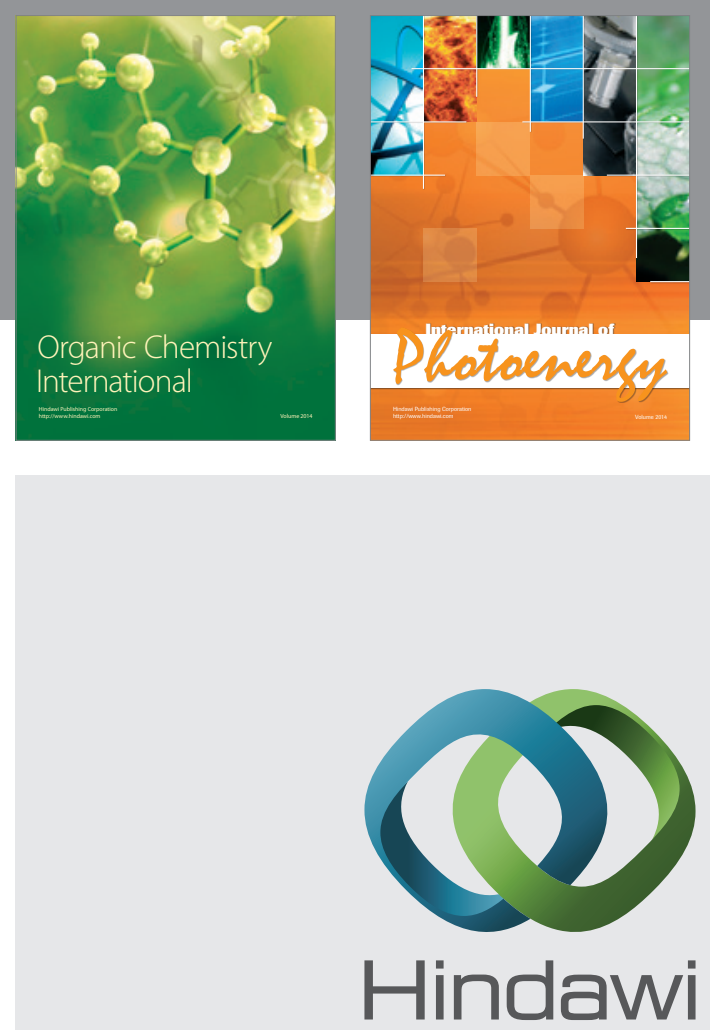

Submit your manuscripts at

http://www.hindawi.com
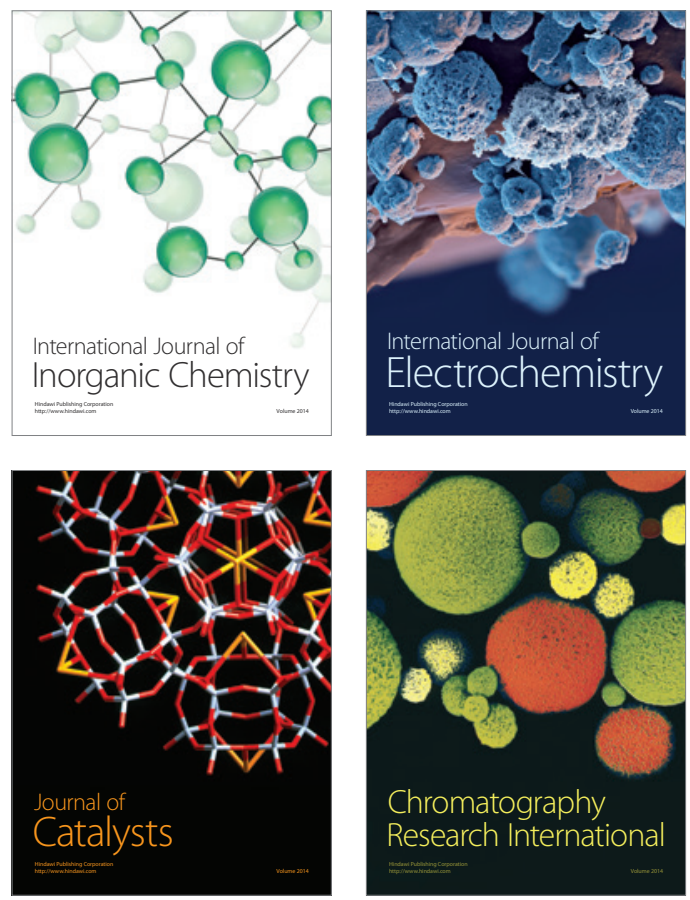
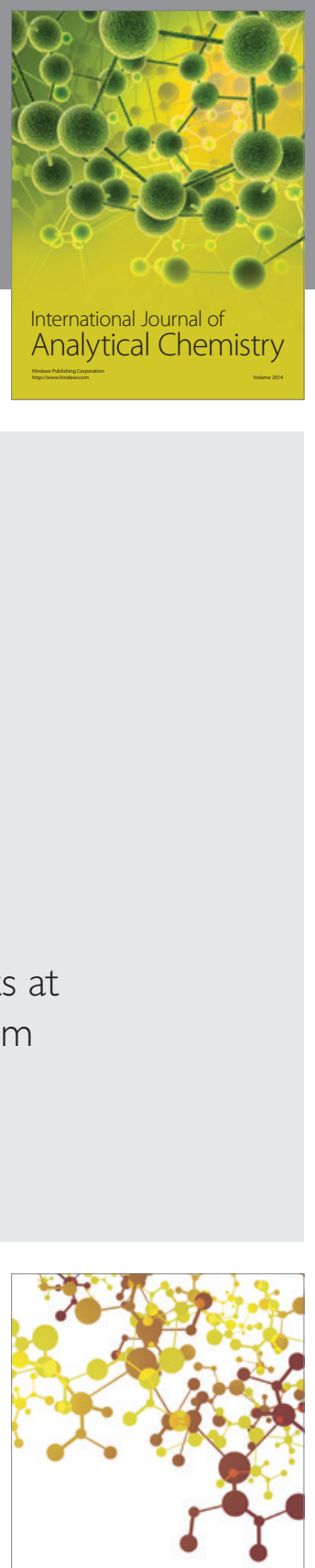

Journal of

Applied Chemistry
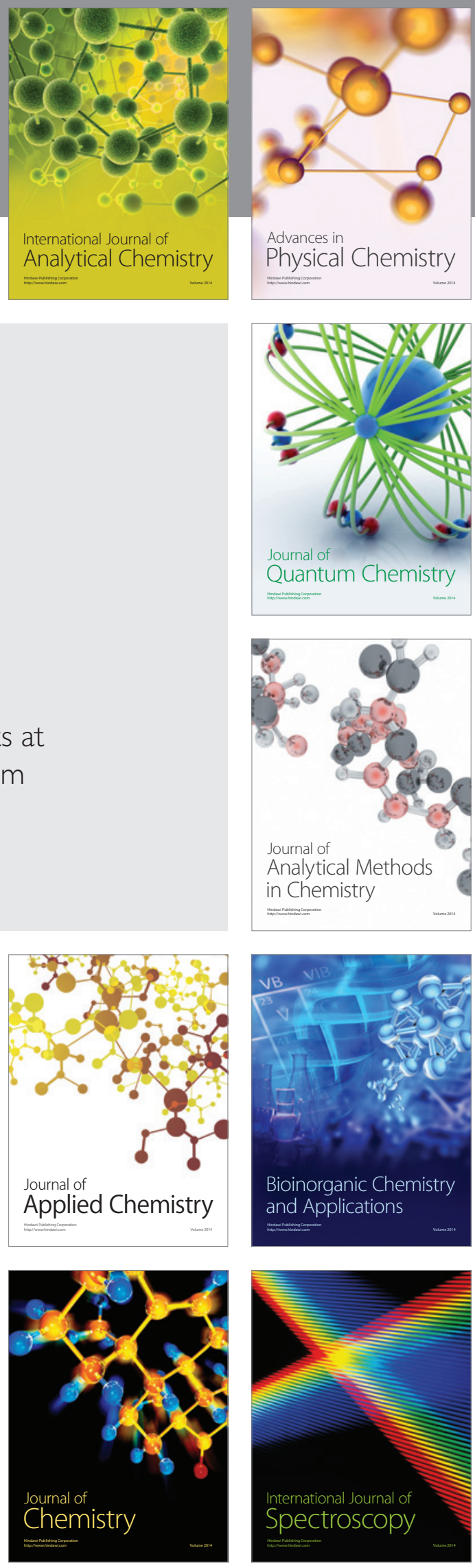